\title{
XAGE3 Gene
}

National Cancer Institute

\section{Source}

National Cancer Institute. XAGE3 Gene. NCI Thesaurus. Code C82958.

This gene may play a role in placental function. 